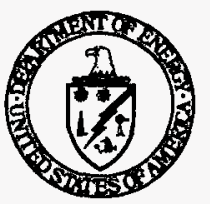

\title{
RCRA Corrective Action and Closure
}

BACKGROUND: In 1980, the Environmental Protection Agency (EPA) promulgated regulations requiring owners/operators of hazardous waste management facillties to perform closure in response to the general mandate in the Resource Conservation and Recovery Act (RCRA) of 1976 to "promulgate regulations establishing such performance standards...as may be necessary to protect human health and the environment." At that time, neither Congress nor EPA realized that dotalled regulatlons requiring owners/operators of hazardous waste management facilities to take corrective action in the event of releases of hazardous wastes and hazardous constluents to the environment would be necessary. Congress and EPA assumed that facilities operated and closed in accordance with the new RCRA requirements would not experience such releases.

In response to increasing evidence that EPA's authority to compel corrective action at operating faclities had to be strengthened, Congress included three provisions in the 1984 Hazardous and Solid Waste Amendments (HSWA) to RCRA giving EPA speciflc correctlve action authority. Section 3004(u) directs EPA to promulgato standards requiring that all RCRA permits address corrective action for releases of hazardous waste or hazardous constituents from solld waste management units (SWMUs). EPA defines SWMUs broadly to include any discernible unit at which solld wastes were placed at any time, regardless of whether the unit was intended for waste management. Section 3004(v) direct EPA to amend existing standards to compel facllity owners/operators to take corrective action beyond the facility boundary. Section 3008(h) provides EPA with the authority to issue administrative orders or bring court action to require corrective action or other measures, as approprlate, for releases of hazardous constituents from a RCRA facility operating under interlm status.

This Information Brief explains how RCRA corrective action and closure processes affect one another. It is one in a serles of Information Briefs on RCRA corrective action.

STATUTE: RCRA Sections 3004(a), 3004(u), 3004(v), and 3008(h).

RECULATIONS: 40 CFR 264, subpart G and Subpart S.

40 CFR 265, Subpart G.

Proposed 40 CFR 264, Subpart $S$ (55 ER 30798 et seg.; July 27, 1980).

REFERENCES: 1. "RCRA Correctlve Action Program Guide - Interim Guidance," U.S. Department of Energy, Office of Environmental Guidance, RCRNCERCLA Division, Guidance Manual, DOEJEH-0323, May 1993.

2. "Closure of Hazardous and Mixed Radioactive Waste Management Units at DOE Facillties," U.S. Department of Energy, Offlce of Environmental Guidance, RCRACERCLA Division, Guidance Manual, DOE/EGD-RCRA-002/0690, June 1980.

3. "RCRA Closure and Post-Closure Plans," U.S. Department of Energy, Office of Environmental Guldance, RCRACERCLA Dlvision, RCRA Information Brief, EH-231-009/1291 (December 1991).

4. "Delay of Closure for RCRA Hazardous Waste Management Facilities," U.S. Department of Energy, Office of Environmental Guidance, RCRACERCLA Division, RCRA Information Brief, EH-231-021/0993 (September 1993).

6. "RCRA Policles on Ground-Water Quality at Closure," U.S. Environmental Protection Agency, Memorandum to the EPA Reglonal Administrators, August 27, 1986.

6. "RCRA Correctlve Action Permit Requirements and Modifications Under Proposed Subpart S Rule," U.S. Department of Energy, Office of Environmental Guidance, RCRACERCLA Division, RCRA Information Brief, EH-231-02310793 (July 1993).

7. “RCRA Post-Closure Permits," U.S. Department of Energy, Office of Environmental Guidance, RCRACERCLA Division, RCRA Information Brief, EH-231-021/0593 (May 1993).

8. "Use of Corrective Action Authorities at Closing Facilities," U.S. Environmental Protection Agency, OSWER Directlve 9502.00-7, May 8, 1988.

9. "RCRA Clean Closure Equivalency Demonstrations," U.S. Department of Energy, Office of Environmental Guldance, RCRACERCLA Division, RCRA Information Brief, EH-231-010/1291 (December 1981).

What are the similarities and differences between RCRA corrective action and closure?

RCRA corrective action is a process for remediating releases of hazardous waste or hazardous constituents from SWMUs. The process involves investigating whether releases have occurred and evaluating, selecting, and implementing remedies to address these releases. A regulator may require a facility owner/operator to perform corrective action at any time during the operational life of a facility, during facility closure, or during the post-closure care period (see Reference 1).
RCRA closure is a process for preventing the release of hazardous waste, hazardous constituents, leachate, contaminated run-off, or hazardous waste decomposition products to the ground water, surface water, or the atmosphere from a hazardous waste management facility after the facility stops receiving waste. The closure process may involve waste removal and management, decontamination and decommissioning of equipment, application of final covers, and other release-preventing actions. The process also involves developing a closure plan, having the plan approved as part of the facility's permit, and implementing the

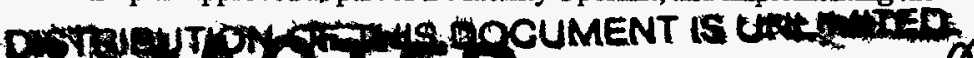
If 19 Printed on Recycled Paper 
plan when the facility closes (see References 2 and 3). Closure occurs after the facility accepts the final shipment of hazardous waste (unless the facility qualifies for a delay of closure) (see Reference 4).

RCRA corrective action and closure are similar in that both are concerned with protecting human health and the environment from damage caused by releases from hazardous waste management facilities. They are different in that corrective action is designed to address releases that have already occurred, while closure is designed toprevent releases after the facility has stopped receiving waste. Related to this difference is the fact that the performance of corrective action is contingent on the occurrence of a release of hazardous waste or hazardous constituents from a SWMU, while closure is a certain event for all hazardous and radioactive mixed waste (RMW) management facilities.

\section{Can the performance of closure lead to corrective action?}

The performance of closure can lead to corrective action if ground water and/or other environmental monitoring data suggest that corrective action is necessary to meet the closure performance standard applicable to hazardous waste treatment, storage and disposal facilities. This standard requires the owner/operator to close the facility in a manner that:

minimizes the need for further maintenance [40 CFR 264.111(a) and 265.111(a)];

$\square$ controls, minimizes, or eliminates, to the extent necessary to protect human health and the environment, post-closure release of hazardous waste, hazardous constituents, leachate, contaminated runoff, or hazardous waste decomposition products to the ground or surface waters or to the atmosphere [40 CFR 264.111(b) and 265.111 (b)]; and

(] complies with other applicable subparts of 40 CFR 264 (for permitted facilities) or 40 CFR 265 (for interim status facilities).

\section{What are the regulators' interests in RCRA facilities undergoing closure?}

Regulators pay close attention to RCRA facilities preparing for and during facility closure because failure to detect environmental problems and compel corrective action at this time may lead to an increase in the number of Superfund sites in the future (see Reference 5). If a regulator requires a facility owner/operator to provide additional environmental monitoring data at the time of closure, it is always possible that such data will suggest the need for corrective action.

\section{How will the need to perform corrective action affect the closure of DOE's permitted facilities?}

For DOE's permitted facilities, corrective action will be performed under the authority of Section 3004(u) of RCRA. The facility's permit will have to be modified, as necessary, to address corrective action (Reference 6).

In many cases, the performance of corrective action will also necessitate changes to a facility's closure plan. For example, a hazardous or RMW management unit may have to be expanded to accept waste generated during corrective action at other SWMUs as part of the remedy for a facility. The closure plan for the facility would have to be amended because expansion of a hazardous or RMW management unit is the type of change that would affect facility closure [40 CFR 264.112(c) and 265.112(c)]. The closure plan amendment could be addressed in a permit modification for corrective action remedy selection or in a separate permit modification (55 FR 30852; July 27, 1990).

\section{How will the need to perform corrective action affect the} closure of DOE's interim status facilities?

For interim status facilities, corrective action may be performed under the authority of an enforcement order issued under Section 3008(h) of RCRA, or the regulator may accelerate the RCRA permitting process and specify corrective action requirements in the facility permit as required under Section 3004(u) of RCRA. If the regulator uses an enforcement order, the order may also discuss facility closure. If the regulator accelerates the RCRA permitting process, corrective action and closure requirements will be specified in the facility's operating permit (as discussed above) or in a RCRA post-closure permit, if the facility is closing or already closed (Reference 7).

When will regulators use RCRA 3008(h) orders and when will they use post-closure permits to compel corrective action at closing facilities?

EPA clarified the use of RCRA Section 3008(h) orders and postclosure permits to address corrective action at closing facilities in a March 1988 memorandum (Reference 8).

First, there are some situations where a RCRA Section 3008(h) order must be used because RCRA Section 3004(u) authority is not applicable. For example, for units not subject to post-closure care [e.g., interim status storage facilities or facilities with surface impoundments that have clean closed according to 40 CFR 270.1(c)(5) and (6)], RCRA Section 3008 (h) orders are the appropriate corrective action authority.

When either RCRA Section 3004(u) or 3008(h) authority may be used (e.g., in the case of interim status land disposal facilities subject to post-closure care requirements), the choice between compelling corrective action in a RCRA Section $3008(\mathrm{~h})$ order or in a post-closure permit is left to the appropriate Regional or State regulator. EPA suggests that regulators consider the following points in deciding how to proceed:

$\square$ A post-closure permit may be an easier approach than a RCRA Section $3008(\mathrm{~h})$ order in the case of a willing owner/operator.

$\square$ In situations which will require long-term oversight, it may be more appropriate to use a post-closure permit because permits are designed to address long-term activities.

$\square$ A RCRA Section 3008(h) order may be more appropriate where prompt action is necessary and a post-closure permit cannot be issued soon.

( A RCRA Section 3008(h) order may be more appropriate than a post-closure permit if releases could be coming from sources other than SWMUs. This is because the language of RCRA Section $3008(\mathrm{~h})$ is broader than the language of Section $3004(\mathrm{u})$ and refers to releases from facilities rather than from SWMUs.

Questions of policy or questions requiring policy decisions will not be addressed in EH-231 Information Briefs unless that policy has already been established through appropriate documentation. Please refer any questions concerning the subject matter covered in this Information Brief to Jerry Coalgate, RCRA/CERCLA Division, EH-231, (202) 586-6075. 


\section{DISCLAIMER}

This report was prepared as an account of work sponsored by an agency of the United States Government. Neither the United States Government nor any agency thereof, nor any of their employees, make any warranty, express or implied, or assumes any legal liability or responsibility for the accuracy, completeness, or usefulness of any information, apparatus, product, or process disclosed, or represents that its use would not infringe privately owned rights. Reference herein to any specific commercial product, process, or service by trade name, trademark, manufacturer, or otherwise does not necessarily constitute or imply its endorsement, recommendation, or favoring by the United States Government or any agency thereof. The views and opinions of authors expressed herein do not necessarily state or reflect those of the United States Government or any agency thereof. 


\section{DISCLAIMER}

Portions of this document may be illegible in electronic image products. Images are produced from the best available original document. 